What is the truth? A demonstration of language manipulation in two newspapers and the pedagogical implications

Farahani, Elham

University of Arak, Iran (Efarahani2007@gmail.com)

Ahmadian, Moussa

University of Arak, Iran (M-ahmadian@araku.ac.ir)

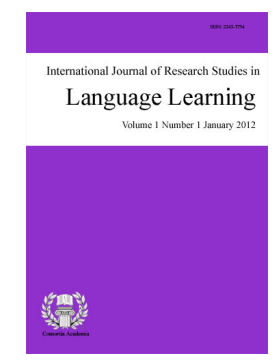

ISSN: 2243-7754 Online ISSN: 2243-7762

OPEN ACCESS

\title{
Abstract
}

Critical discourse analysis (CDA) aims to show how discourse shapes and is shaped by power relations in society. Conducted in a CDA framework, this study aims to investigate how The Los Angeles Times and Tehran Times represent the reaction of Russia after a speech delivered by Iran's ex-President on May 26, 2010 in order to have a consciousness-raising about the power of language in changing one's view about the events, and, more importantly, to shed light on the implications of CDA for language pedagogy. In this study, Van Dijk's (2000) framework was employed to detect the discursive strategies used by the two newspapers. After the analyses of news reports, it was found that the two newspapers represent the reaction of Russia significantly differently to their readers, based on their different ideologies by using two overall semantic macro-strategies of positive self-presentation and negative other-presentation which are realized by other discursive strategies such as lexicalization, repetition, vagueness, illegality, and history as lesson.

Keywords: critical discourse analysis (CDA); Van Dijk's (2000) framework; ideology; newspapers; discursive strategies 


\section{What is the truth? A demonstration of language manipulation in two newspapers and the pedagogical implications}

\section{Introduction}

Mass media in general and newspapers in particular have always received the attention of many CDA practitioners from the beginning of its evolution. CDA practitioners opt for newspapers discourse to investigate the representation of different social and political issues such as racism, gender inequality, wars and so on. The reason for this assiduous attention in CDA studies is due to the nature of news discourse as being ideologically loaded and manipulative. Reah (2002) mentions that "newspapers represent acts in a way that will influence the reader's view of them" (p. 73), and that news is ideological representation of events.

"Newspapers have no or little power over the readership's attitudes, but they have a great power in deciding what issues readers consider important" (Nordland, 2003, p. 3). They have the power to do so through the process of newsworthiness, and since the ultimate goal of CDA is that of consciousness- raising, CDA scholars choose newspapers to base their critical analysis on in order to resist the power of newspapers in manipulating, and influencing people's ideas in a way that is in favor of the elite of the society.

In the same vein, this study uses Van Dijk's (2000) framework to elucidate how one single event: the reaction of Russia after a speech delivered by Iran's ex-President on May 26, 2010 is represented in The Los Angeles Times and Tehran Times and to investigate whether there is any bias in the representation of this event in the two newspapers. Thus, the main research question in this study is:

How ideological differences manifest themselves in the discourse of the Los Angeles Times and Tehran Times dealing with the reaction of Russia?

Bearing all these in mind, the major purposes of this study are to show how media workers and journalists' linguistic choices differ from one ideological point of view to another in the treatment of the same event (Russia's stance towards Iran). From a practical perspective, its goal is the same 'wake-up call' and consciousness raising, which most CDA practitioners consider to be their ultimate goal along with changing the situation. About this aim, Reah (2002) states: "... it is important that readers of newspapers become critical readers who are aware of, and can identify, gaps and swings in the information they are given (p. 10). Moreover, based on the findings of this study, some possible implications for EFL context are suggested.

\section{Review of literature}

\subsection{Critical discourse analysis}

CDA is concerned with discourse in forming and being formed by social political practices (Fairclough, 2001). It is not a single, homogenous method or approach but a paradigm of research, a program, or as Wodak (2001) suggests, a school, with leading scholars who have different backgrounds of their own and have their own approaches with different analytical tools. According to Wodak (2001), this heterogeneous quality of CDA "allows for open discussions and debates for changes in the aims and goals, and for innovation" (p. 8). However, all CDA methods share a view about the "social processes of power, hierarchy building, exclusion and subordination" (Meyer, 2001, p. 3). Racism, gender inequality, sexism, xenophobia, colonialism, employment, war, nuclear weapons and nuclear power (Fowler, 2002) are among the topics in which most of critical discourse analysts are interested. In general, CDA aims to raise the readers' consciousness of the power of language in changing the events and influencing the readers' views. 
One of the key concepts in CDA is ideology which is defined as "systems of ideas which are socio-cognitively defined as shared representations of social groups and more specifically as the 'axiomatic' principles of such representations" (Van Dijk, 2006). In CDA, discourse is believed to be involved in the reproduction of ideologies. Of course, there are many ways in which ideology can be reproduced, but discourse plays a fundamental role in daily expression of ideology (Van Dijk, 1995). In fact, the ultimate goal of CDA is to lay bare the injection of ideologies in discourses of different types. To do this, Van Dijk (1998a, 2000, 2006) provides a theoretical framework which he calls the socio-cognitive model and mentions that ideology and discourse are not notions that can be adequately studied in just one discipline and it requires analysis in fields of humanities and social sciences. However, he reduces this large number of potential disciplines to three main clusters, namely: those involved in the study of discourse, cognition, and society. The departure point of this model from other CDA models is its emphasis on cognition. For Van Dijk, cognition is of great importance in relating discourse structures and social structures; to him, these two cannot be connected to each other without the interface of cognition (Van Dijk, 2001, 2006).

Another important concept in CDA studies is power and its different dimensions. Van Dijk (1998b) mentions that there is a strong relationship between discourse and the exercise of power in the society and defines social power in terms of control. That is, groups are powerful if they can control the acts and mind of people. He explains that "this ability presupposes a power base of privileged access to scarce social resources such as force, money, status, fame, knowledge, information, 'culture', or indeed various forms of public discourse and communication" (p. 354). Concerning the relations between discourse and power, Van Dijk (1998b) states:

Access to specific forms of discourse, e.g. those of politics, the media, or science, is itself a power resource. Secondly, action is controlled by our minds. So, if we are able to influence people's minds, e.g. their knowledge or opinions, we indirectly may control (some of) their actions, as we know from persuasion and manipulation (p. 355).

Van Dijk (1996) states that one dimension of discursive reproduction of power is related to the concept of access to discourse. Ordinary people have only active access to every day conversations with family members, friends, or colleagues and more passive access to institutional discourse and media discourse. The elites, on the other hand, have access to a vast variety of informal and public discourses (Van Dijk, 1996, 1998a, 2001). Actually, these are the elites who have access and control over the most influential genres of discourse in society. Van Dijk (1995) maintains that elites' control is not limited to discourse; it also includes the control over the mind of people. Of course, this is also a function of discourse, that is, control over and access to public discourse may affect the minds of others (p. 22). Those who are in power can convey knowledge, affect opinions or challenge attitudes. People may not be told the truth and they can be manipulated or influenced against their willing. People may also do not have access to alternative sources of information and their information may be limited to only those sources that are under the control of the dominant group or they may be ignorant of the power of language, and its strategies to manipulate or influence their opinions.

\subsection{CDA and EFL}

Many studies have been conducted relating to the pedagogical implications of CDA for EFL contexts. They mostly share the view that CDA can be a means for EFL teachers to improve at least the learners' thinking abilities, critical reading and writing skills. Koupaee (2010) investigated the effect of using CDA to raise EFL students' Critical Language Awareness (CLA). The participants in this study were sixty BA students with an intermediate or advanced proficiency level of English language who were studying English at the University of Kashan, Iran. According to her, these levels of proficiency were opted for since teaching CDA techniques to students with lower levels may not be appropriate to make use of CDA analytical tools in their reading classes, as "CDA requires at least some ability to distinguish differences between such things as grammar patterns or synonyms" (p. 36). Three paired news articles with the same or similar subjects were given to the students to 
Farahani, E. \& Ahmadian, M.

detect the hidden meaning in the texts once before and once after teaching them some CDA analytical tools based on Van Dijk (1998b) framework. Then the participants were asked to respond to a questionnaire to reveal any change in their opinions about English language learning or "any increase in their motivations to learn English" (p. 39). Analyzing the students' responses to the questions, it was found that CLA of about $90 \%$ of students improved and their motivation to learn English also increased.

Asgharzade (2009) investigated the effect of teaching critical reading through CDA on some of female high school students' reading comprehension in Kermanshah, Iran. To this aim, a proficiency test was given to one hundred students then fifty students with higher grades were selected as the participants of this study. These selected participants were divided into two groups: experimental and control. Students in the control group were taught reading in ordinary ways, but students in the experimental group were taught reading through CDA tools. After this period of instruction, two reading tests were given to the two groups. The results showed that the students who were familiar with CDA got higher marks than to those students in the control group.

Cots' (2006) is another study on the application of CDA to EFL classrooms. He concludes that:

Introduction of Critical Discourse Analysis (CDA) in language classes does not necessarily
involve a change in teaching method or techniques. Rather, CDA offers a new perspective on
language, which considers that language use $(a)$ is questionable and problematic, $(b)$ reflects
social/ideological processes, and $(c)$ constitutes, at the same time, a resource to act upon those
processes (p. 336$)$.

In his Article, Cots (2006) showed that the choices of the teachers and material developers can be critically investigated in the EFL classes with the company of the learners to develop the learners' capacity to be critical readers of their world. By presenting a short reading text and its following activities from an EFL textbook, Cots tried to point to the inefficiencies of such activities in EFL classes which required only a reading for literal meaning, because such a text and the activities were not a complete representation of language use. The reasons he mentioned for this inefficiency are that: 1) the activities did not make the learners to involved in interpreting the text in terms of its social structures and ideological effects, 2) the activities did not pay attention to the production and consumption of the text such as "authorship, purpose, intended audience, print source, and connections with other texts" (p.338), 3); although the activities required a structural focus, they failed to show how the structures could convey a particular ideology. In another part of his practical article, Cots presented an activity which would involve students in critically reading of the texts, following Fairclough's (2001) three level framework of CDA. Having introduced this kind of reading activity, he emphasized that the activity suggested were complementary and not an alternative to the common activities in EFL reading classes. At the end, using Willis' (1996) task cycle which has three stages: pre-task, task cycle, and language focus, he also showed how CDA can be implemented in EFL classes. The most interesting and practical part of Cots' article, trying to pave the way for language teachers to use CDA tools in EFL classes, is that he included a list of questions that " may be used by teachers (a) to approach language use with a 'critical ' attitude, and (b) as a reference framework to plan how to present language use to learners" (Cots, 2006, p. 344).

\section{Methodology}

\subsection{Data selection and sampling}

The sources of data for this study were two newspapers: The Los Angeles Times and Tehran Times. The main reason for selecting these newspapers is that The Los Angeles Times is one of the top American newspapers, and Tehran Times is one of the Iranian newspapers in English which is published in Iran and other countries. Moreover, these newspapers can be easily accessed in their websites.

For collecting the data, a period of 37 days, from May 15 to June 21, 2010, was selected to collect news 
reports. Then, out of these collected news reports, the researchers decided to find subjects about which the newspapers had published some reports on the same date. In order to find these shared subjects, all the headlines of the collected data were carefully studied. Having done this, the researchers found two news reports published on the same date about Russia's reaction towards a speech delivered by Iran's ex-President criticizing the Russian officials.

\subsection{Methodological framework}

In this research, Van Dijk's (2000) framework was opted for as the basis of the analyses. This framework is based on an ideological square which presents a general and practical strategy of ideological analysis, and thus can be applied to the analysis of ideological discourse at all levels of discourse. This ideological square has these four principles: "Emphasize positive things about US. Emphasize negative things about Them. De-emphasize negative things about Us. De-emphasize positive things about Them" (Van Dijk, 2000, p.44).

The semantic macro-strategies of positive self-presentation employed either for individual face keeping or for collective purposes by focusing on the positive aspects of one's group, and negative other-presentation which is related to the use of derogatory terms and focusing on the negative characteristics of out-group members (Van Dijk, 2000) are the bases of this framework. These two macro-strategies are realized by other forty discursive strategies which are potentially possible to occur in different kinds of ideological discourses. However, using this framework in a study, one cannot expect that all these forty strategies to be found in the discourses to be analyzed. The most common discusive strategies of this framework found in the news reports in this study along with descriptions according to Van Dijk (2000) are as follows:

$>$ Disclaimer: This strategy is used to keep face by stating our positive characteristics first, and then focus on their negative attributes.

$>$ Distancing: A socio-cognitive device which may, for instance, be employed by the use of demonstrative pronouns instead of naming or describing Others.

$>\quad$ History as lesson: Sometimes a situation is compared to positive or negative events in history, either as a positive self-presentation or negative other-presentation strategy.

$>\quad$ Illegality: A device by which the out-group members are characterized as criminal or law breaker.

$>$ Number Game: The use of numbers and statistics in the discourse is a means to show that the writers/speakers are objective and that what they are discussing is not just their opinions but 'facts'.

$>$ Polarization, Us-Them categorization: This is a prevalent semantic strategy which divides people in two groups of in-group (US) and out-group (THEM).

$>$ Repetition: Repetition as a rhetorical device has a specific function in the general strategy of emphasizing Our positive things and Their negative ones.

$>$ Presupposition: Van Dijk compares discourses to icebergs, in the sense that most of the meanings of a text are not explicitly expressed but presupposed to be known by the recipients. Presuppositions are used typically to speak about the controversial ideas or to assume the truth of some preposition when such truth is not accepted at all.

$>\quad$ Pseudo- ignorance: This strategy may be used to derogate out-groups without any verification. In this case, speakers/ writers do not have specific information about a subject but implicitly put forward that they know about it. This kind of an 'apparent knowledge' generally appears in disclaimers, like: "I do not know, but..."

$>\quad$ Vagueness: Speakers/writers may make use of vague expressions like: 'few', 'a lot', 'very', 'thing', 
'low', and 'high' in order not to give enough information to the readers/ listeners either as a positive self-presentation or a negative other-presentation.

\section{CDA of the news reports, results and discussion}

\subsection{Background}

This study is about Russia's reaction after a speech delivered by Iran's ex-President on May 26, 2010. In this speech, Iran's ex-President lashes out at Russia for supporting the U.S. and adopting negative stances towards Tehran's declaration which was signed by Iran, Brazil, and Turkey on May17. According to this declaration, Iran was called for to send 1200 kilograms of its low-enriched uranium to Turkey to be traded for 120 kilograms of 20 percent enriched nuclear fuel. Iran considered this deal as "a constructive movement" initiated by Iran to show its cooperation with the United Nations Security Council in solving the debates over its nuclear program. Contrary to what was expected by Iran, America and other permanent members of the UN Security Council did not consider this as an influential step and insisted on the imposition of further sanctions against Iran.

The content of this speech is not attended to in this part, what is interesting here is to show how differently the two American and Iranian newspapers represent a single event, namely the reaction of Russia after Iran's President's speech to their readers and how the language is manipulated by using different discursive strategies to convey a meaning according to one's interests and ideologies.

\subsection{CDA of the Los Angeles Times' report}

The Los Angeles Times selects this headline and lead paragraph for its news report (Stark, 2010):

\section{Russia lashes out at Iran}

The verb "lashes out" used in this headline means: "to criticize somebody in an angry way" (Hornby, 2004). This word connotes anger and impatience and by this lexical choice, the writer wants to convey that Russia is so angry at Iran that cannot tolerate Iran's acts any more. This lexical choice works towards negative other-presentation. The lead paragraph also contains negative and derogatory terms when speaking about Iran and when describing the reaction of Russia towards the speech:

Lead: Foreign Minister Sergei Lavrov dismisses Iranian criticism that Russia is susceptible to Western influence and says Tehran has obstinately refused to address about its nuclear program.

In this lead, it is told that Lavrov has dismissed Iran's President's criticism and the writer indirectly quotes Lavrov as saying: "Tehran has obstinately refused to address concerns about its nuclear program". In this sentence, by the writer's use of an indirect quotation, it is not clear whether these derogatory words are Lavrov's words or the interpretations of the writer injected in this sentence. Moreover, there is a sense of illegality in this lead about Iran which refuses to deal with its nuclear problems.

In this report, there are many negative and derogatory terms about Iran and its relationship with Russia. This kind of lexicalization by the writer gives a negative image of Iran:

1)...dismissed criticism from the Iranian president as "emotional", and expressed frustration over what he portrayed as Tehran's obstinate refusal to...

2) ...lashed backed at Iranian President Mahmoud Ahmadinejad, who a day earlier described the Kremlin as a potential enemy...

5) "Iran's response was unsatisfactory, to say the least". 
A demonstration of language manipulation in two newspapers and the pedagogical implications

8) The Russian leadership was outraged by his remarks. A Kremlin aide, foreign policy advisor Sergei Prikhodko, on Wednesday accused Ahmadinejad of "political demagoguery."

9) The rhetoric reflects a new depth of Moscow's impatience with Tehran...

12) ..., and criticized Iran for wasting time by rejecting the earlier offer.

In paragraph1, the writer mentions that a top Russian official dismissed Iran's President's criticism as emotional. This is the only word that is chosen to be quoted directly and this choice is obviously ideologically loaded, since it is a derogatory term aimed at negative other-presentation.

In paragraph 11 (below), the writer uses the word "ploy" to refer to the deal signed on May 17 implying that this deal is considered by the United States as a strategy to avoid the sanctions not as an effort which shows Iran's "good will".

11) The United States has dismissed the deal as a ploy to buy time and avoid sanctions.

In paragraph 12, the writer refers to the deal which was proposed by the International Atomic Energy Agency in October 2009 and rejected by Iran. Here the strategy of history as lesson is used by referring to this deal. The write wants to convey that the deal suggested by Iran on May 17 cannot be trusted upon since it is the repetition of that previous one which Iran refused to act upon.

12) .... He pointed out that much of the recent agreement was recycled from a proposal made in 2009 by the International Atomic Energy Agency, and criticized Iran for wasting time by rejecting the earlier offer.

An interesting point about this news report is the way the writer presents the information and the events. He begins the report with some quotations from Russian officials, all of them conveying a sense of anger and impatience towards Iran in general, and the speech delivered by Iran's ex-President on May 26 in particular. Then, by the use of the sentence :"But it was not all tough talk", nearly at the end of the report, in paragraph 13, the writer changes the tone and begins to mention some positive words and phrases about Russia and Iran's relationship. In this part, he also refers to the telephone call initiated by the Russian officials to the Iranian officials on Thursday, one day after the Iran's ex-President's speech. This way of ordering the information related to an event in the text is highly ideological, since the writer first focuses on the negative parts related to the Others, and then at the end of the text mentions some minor information about the positive points, as a strategy to emphasize negative things about Them and de-emphasize positive things about Them which are two parts of Van Dijk's (2000) ideological square.

The following paragraphs taken from this report show the change of tone about the relationship between Iran and Russia which are presented at the end of the report:

13) But it wasn't all tough talk. The deliberate ambivalence that has long characterized Moscow's stand on Iran was still in full view Thursday as Russian officials made a deliberate show of calling for further negotiations to help Iran sidestep sanctions.

14) Despite the sharp tone from the podium, Lavrov phoned his Iranian counterpart and pledged to "actively work to promote" further nuclear talks, the Foreign Ministry said.

16) On Thursday, another Russian official hastened to explain that new sanctions would have no bearing on existing trade deals with Iran.

4.3 CDA of Tehran Times' report

Tehran Times chooses this headline and lead paragraph for its report ("Russia supports", 2010): 


\section{Russia supports Iran's nuclear fuel pact}

Lead: On day after President Ahmadinejad severely criticized Russia for siding with the U.S. on the Tehran nuclear agreement, two top Russians (sic) officials announced that the Kremlin is ready to support the nuclear fuel swap deal signed between Iran, Turkey and Brazil.

In the headline, it is claimed that Russia supports Iran's nuclear fuel swap. By this choice of positive verb in the headline, one can expect that the image that Tehran Times will draw of the stance of Russia towards Iran is positive and supportive. The writer also begins the lead with: "On day after President...", to imply that the speech which was delivered by Iran's ex-President was so influential and impressing that just one day after the speech, Russian officials changed their stance towards the deal and announced their readiness to support the deal. In this lead, it is said that "two top Russians (sic) officials", without naming them, announced the Kremlin's readiness to support the deal. The use of this vagueness strategy and an indirect quotation is interesting here since the writer by using these strategies smartly avoids any responsibility for the words mentioned. In this way, it is not clear whether the part: "the Kremlin is ready to support the nuclear fuel swap..." is told by the Russian officials or it is the interpretation of the writer of the report.

Reading this report critically, one can observe that all the lexical choices which describe Russia's reaction towards Iran are positive, conveying a sense of support and friendship and there is not even one word to convey a sense of disagreement on the part of Russia: ready, backs, support, energetically, contribute, positive, friendly relations, peaceful resolution, actively support, and assist. Here are the quotations of Russian officials used in this report:

Lead) ... the Kremlin is ready to support the nuclear fuel swap deal signed between Iran, Turkey and Brazil

2) Patrushev said his country backs nuclear swap on the Turkish territory.

3) Moscow is ready to energetically contribute to a settlement of the problem concerning the Tehran declaration, the Voice of Russia quoted Patrushev as saying.

4) Patrushev also said that Russia believes the outlook for Tehran-Moscow cooperation is positive.

5) For his part, Jalili said, "The Tehran declaration is a positive step for interaction that should be complemented by other side's positive steps."

6) He went on to say that Iran and Russia's common interests and threats necessitate the two nations to maintain friendly relations.

7) ... Lavrov said the Tehran agreement may see a peaceful resolution to the nuclear standoff between Iran and the west.

8) "The scheme (on uranium swap) meets the requirements for a peaceful resolution of Iran's nuclear issue, that is why we will do everything possible to implement it," RIA Novosti quoted Lavrov as saying during a news conference on Thursday.

9) "If (Iran) strictly follows (its obligations), Russia will actively support the scheme proposed by Brazil and Turkey," Lavrov stated.

10) Lavrov said that Moscow will assist the negotiating process to break the impasse over Iran's nuclear program.

11) "The Russian side expressed readiness to provide active assistance in advancing the negotiating process on the settlement of the Iranian nuclear program issue," the Russian Foreign Ministry said in a statement posted on its website. 
A demonstration of language manipulation in two newspapers and the pedagogical implications

In the paragraphs cited above, there are three repetitions of positive lexical choices. 'Support' is repeated in the headline, in the lead, and in paragraph nine, the word "peaceful" is also repeated in paragraphs seven and eight, and the word "positive" is repeated in paragraphs four and five.

In paragraph five, the use of other in the phrase "other side's positive steps" is a kind of polarization.

As was shown in the CDA of the new reports, the lexical choices deployed in the two news reports are in marked contrast to each other. In Tehran Times' report, all the lexical choices that are used to describe Russia's relationship with Iran are positive which are working towards the overall strategy of positive self-presentation. The writer, by using the strategy of lexicalization, most frequently pictured a completely friendly and supportive relationship with Iran. However, on June 9, 2010, Russia was not that much friendly and supportive as was reported by Tehran Times' report since Russia was among those countries that voted in favor of the fourth round of sanctions against Iran endorsed by UN Security Council. On the other hand, The Los Angeles Times gave a negative image of the relationship between Iran and Russia. This contrast is shown in Table 1.

\section{Table 1}

Lexical Choices in Tehran Times and the Los Angeles Times' News Reports

\begin{tabular}{|c|c|}
\hline Tehran Times & Los Angeles Times \\
\hline $\begin{array}{l}\text { Two top Russian officials announced that } \\
\text { Kremlin is ready to support the nuclear fuel } \\
\text { swap... }\end{array}$ & Lavrov dismisses Iranian criticism that... \\
\hline $\begin{array}{l}\text { Patrushev said his country backs nuclear } \\
\text { swap... }\end{array}$ & $\begin{array}{l}\text { A top Russian official expressed frustration } \\
\text { over... }\end{array}$ \\
\hline $\begin{array}{l}\text { Moscow is ready to energetically contribute } \\
\text { to... }\end{array}$ & Lavrov lashed back at Iranian... \\
\hline $\begin{array}{l}\text { Patrushev also said...the outlook for } \\
\text { Tehran-Moscow cooperation is positive. }\end{array}$ & Iran's response was unsatisfactory, Lavrov said \\
\hline $\begin{array}{l}\text { Lavrov said the Tehran agreement may see a } \\
\text { peaceful resolution to the nuclear standoff... }\end{array}$ & The Russian leadership was outraged by... \\
\hline $\begin{array}{l}\text { Lavrov said that Moscow will assist the } \\
\text { negotiating process... }\end{array}$ & $\begin{array}{l}\text { Prikhodko...accused Ahmadinejad of "political } \\
\text { demagoguery" }\end{array}$ \\
\hline $\begin{array}{l}\text { The Russian side expressed readiness to } \\
\text { provide active assistance in advancing the } \\
\text { negotiation process... }\end{array}$ & Lavrov criticized Iran for wasting time... \\
\hline
\end{tabular}

This table manifests how these two newspapers give completely different pictures of the reaction of Russia towards Iran after the speech, in particular, and its relationship with Iran, in general. The words that are used in Tehran Times' report are all positive, implying a sense of friendship. On the other hand, the words that are used in The Los Angeles Times are negative, giving an image of anger and hostility on the part of Russia towards Iran. Moreover, another interesting ploy which is employed in these two new reports is related to the manipulation of the discourse form, in order to disseminate their favorite ideologies and perspective.

In Tehran Times' report, the writer focuses on a telephone conversation which was initiated by the Russia's officials at the beginning of the news reports, but The Los Angeles Times' writer does not refer to this telephone call until the end of the news report. This way of presenting the events in discourse is highly ideological. This finding supports Van Dijk (2000) who states that:

Information that is favorable for or about the own group or unfavorable for the out-group will tend to be topical, important and explicit. Information that portrays us in a negative light will tend to remain implicit, not topicalized, hidden, vague, and little detailed (p.78).

Representation of a single subject, namely Russia's stance and relationship with Iran, in such contrasting ways by The Los Angeles Times and Tehran Times lends support to Fowler's (1991) claim that: "news is not just a value-free reflection of facts. Anything that is said or written about the world is articulated from a particular 
Farahani, E. \& Ahmadian, M.

ideological position" (p. 101).

\section{Conclusions}

The most frequent strategies which are used in Tehran Times' report are lexicalization and repetition. These two strategies, along with other strategies of vagueness and polarization, are used to give a positive image of the reaction of Russia towards Iran. Similarly, in The Los Angeles Times' report, lexicalization is the most frequent strategy which is used by the writer to give a negative image of the reaction of Russia towards Iran after the speech. The results obtained from the CDA analyses of the news reports showed that ideological manipulations of language can be realized by the deployment of the two general semantic macro-strategies of Van Dijk's (2000) framework: positive self-presentation and negative other-presentation which are manifested by other discursive strategies within this framework.

Considering the findings of this study which was focused on the discourse of newspapers, one can conclude that the only way we, human begins, as seekers of truth, can get access to the truth of the events around us is that we have to approve the reality from different perspectives, take every variable into account, and examine the truth value of the utterances and the source of information which we encounter in our daily lives. The findings of this research and other similar studies on CDA which focused on the discourse of newspapers (Hodge \& Kress, 1979; Van Dijk, 1998b; Teo, 2002; Caldas-Coulthard, 2003; etc.) show that the events are not represented in the newspapers as they are in reality but they go through journalistic practices.

\subsection{Pedagogical implications}

The finding of this study can have some implications for language pedagogy and EFL contexts, the sketches of which are as follows:

The first possible implication of this study is that of consciousness-raising, as it is the ultimate goal of CDA. This study has a wake-up call for students to be aware of the power of language in changing and even making their points of view and opinions about the events, the people, and the world around them. This awareness of the power of language in inculcation of ideologies are highly vital for EFL learners since they are exposed to a variety of authentic materials such as textbooks and movies which are produced by the native speakers of English. As such, EFL learners can "act as transmitters of foreign thoughts and beliefs to their own culture" (Koupaee, 2010, p. 1). Therefore, EFL learners should be aware of the possible latent meanings that are injected in these materials, to resist the imposition of ideologies on them.

CDA of the news reports done and the framework which was used in this study can also be insightful in the courses that deal with journalism. EFL teachers of these courses can introduce some of the categories of this CDA framework to their students and want them to critically analyze the news they are reading in the class or in their daily life. By doing this, the teachers help EFL students to be equipped with some analytical tools to detect the hidden meanings in the newspapers. Moreover, the findings of this study can be used to improve students' reading skills. Making use of CDA tools in reading classes can improve the reading skills of EFL learners, as was proved by (Asgharzadeh, 2009). By the use of CDA tools, the learners learn to read between the lines and understand the real intention of the writers.

The other implication of this study for EFL contexts is that using CDA tools in EFL classes can increase EFL learners' creativity, motivation and activity (Farahani, 2011). In relation to this implication, Rahimi and Sahragard (2007) state that: "second language learning will doubtless be a debacle or a distressingly frustrating experience unless the intricate cultural pragmatic constraints on communication, reading and writing are brought to the limelight" (p. 134). A further pedagogical implication of this study is related to the improvement of students' critical thinking and critical language awareness. By using CDA analytical tools and techniques, the learners become able to examine the world more cautiously and not to take everything for granted and ignore the acceptance of what meets the eyes. 
A demonstration of language manipulation in two newspapers and the pedagogical implications

Finally, the findings of this study can be insightful for EFL teachers to be aware of the discourse they use in their classes since every seemingly innocent word they use in their speech can have some unexpected consequences on their EFL learners who consider their teachers as models for learning English.

\section{References:}

Asgharzadeh, R. (2009). The effect of teaching critical reading through critical discourse analysis on high school EFL learners' reading comprehension. Unpublished masteral thesis, University of Shiraz, Iran.

Cots, J. M. (2006). Teaching with 'an attitude': Critical discourse analysis in EFL teaching. ELT Journal, 60(4), 336-345. http://dx.doi.org/10.1093/elt/ccl024

Caldas-Coulthard, C. R. (2003). Cross-cultural representation of 'otherness' in media discourse. In G. Weiss \& R. Wodak (Eds.), Critical discourse analysis: Theory and interdisciplinarity (pp. 272-296). London: Palgrave Macmillan.

Fairclough, N. (2001). Language and power ( $2^{\text {nd }}$ ed.). London: Longman.

Farahani, E. (2011). A critical discourse analysis of Los Angeles Times and Tehran Times on the representation of Iran's nuclear program and the pedagogical implications. Unpublished masteral thesis, University of Arak, Iran.

Fowler, R. (1991). Language in the news: Discourse and ideology in the press. London: Routledge.

Fowler, R. (2002). On critical linguistics. In M. Toolan (Ed.), Critical discourse analysis: Critical concepts in linguistics (vol. 1, pp. 346-357). London and New York: Routledge.

Hodge, R., \& Kress, G. (1979). Language as ideology. New York: Routledge.

Hornby, A. S. (Ed.). (2004). Oxford advanced learner's dictionary. London: Oxford University Press.

Koupaee, D. Z. (2010). Teaching reading with a critical attitude: Using critical discourse analysis (CDA) to raise EFL university students' critical language awareness (CLA). Unpublished masteral thesis. University of Kashan, Iran.

Meyer, M. (2001). Between theory, method, and politics: Positioning of the approaches to CDA. In R. Wodak \& M. Meyer (Eds.), Methods of critical discourse analysis (pp. 14-31). London: SAGE.

Nordland, M. (2003). Linguistic manipulation: An analysis of how attitudes are displayed in news reporting. Retrieved April 5, 2010, from http://www-staff.lboro.ac.uk/ ssjer/SLCl/SLC

Rahimi, A., \& Sahragard, R. (2007). Critical discourse analysis. Tehran: Jungle Press.

Reah, D. (2002). The language of newspapers ( $2^{\text {nd }}$ ed.). London: Routledge.

Russia supports Iran's nuclear fuel pact. (2010, May 29). Tehran Times. Retrieved from http://www.tehrantimes.com/

Stack, M. K. (2010, May 28). Russia lashes out at Iran. The Los Angeles Times. Retrieved from http://www.latimes.com/

Teo, P. (2002). Racism in the news: A critical discourse analysis of news reporting in two Australian newspapers. In M. Toolan (Ed.), Critical discourse analysis: Critical concepts in linguistics (vol.4, pp. 360-404). London and New York: Routledge.

Van Dijk, T. A. (1995). Discourse analysis as ideology analysis. In C. Schaffner \& A. Wenden (Eds.), Language and Peace (pp. 17-33). Aldershot: Dartmouth Publishing.

Van Dijk, T. A. (1996). Discourse, power and access. In R. C. Coulthard \& M. Coulthard (Eds.), Texts and practices: Reading in critical discourse analysis (pp. 84-104). New York: Routledge.

Van Dijk, T. A. (1998a). Opinions and ideologies in the press. In A. Bell \& P. Gamet (Eds.), Approaches to media discourse. Oxford: Blackwell Publishers.

Van Dijk, T. A. (1998b). Critical discourse analysis. Retrieved September 15, 2009, from http://www.hum.uva.nl/ teun/cda.htm

Van Dijk, T. A. (2000). Ideology and discourse: A multidisciplinary introduction. Retrieved June 23, 2010, from http://www.discourses.org

Van Dijk, T. A. (2001). Multidisciplinary CDA: A plea for diversity. In R. Wodak \& M. Meyer (Eds.), Methods of critical discourse analysis (pp. 95-120). London: SAGE. http://dx.doi.org/10.4135/9780857028020.d7 
Farahani, E. \& Ahmadian, M.

Van Dijk, T. A. (2006). Ideology and discourse analysis. Journal of Political Ideologies, 11(2), 115-140. http://dx.doi.org/10.1080/13569310600687908

Willis, J. (1996). A framework for task-based learning. London: Longman

Wodak, R. (2001). What CDA is about - A summary of its history, important concepts and its developments. In R. Wodak \& M. Meyer (Eds.), Methods of critical discourse analysis (pp. 1-13). London: SAGE. 